\title{
Light and Circadian Signaling Pathway in Pregnancy: Programming of Adult Health and Disease
}

\author{
Chien-Ning Hsu ${ }^{1,2}$ (D) and You-Lin Tain ${ }^{3, *} \mathbb{C}$ \\ 1 Department of Pharmacy, Kaohsiung Chang Gung Memorial Hospital, Kaohsiung 833, Taiwan; \\ chien_ning_hsu@hotmail.com \\ 2 School of Pharmacy, Kaohsiung Medical University, Kaohsiung 807, Taiwan \\ 3 Department of Pediatrics, Kaohsiung Chang Gung Memorial Hospital and Chang Gung University College \\ of Medicine, Kaohsiung 833, Taiwan \\ * Correspondence: tainyl@hotmail.com; Tel.: +886-975-056-995; Fax: +886-7733-8009
}

Received: 6 February 2020; Accepted: 22 March 2020; Published: 23 March 2020

\begin{abstract}
Light is a crucial environmental signal that affects elements of human health, including the entrainment of circadian rhythms. A suboptimal environment during pregnancy can increase the risk of offspring developing a wide range of chronic diseases in later life. Circadian rhythm disruption in pregnant women may have deleterious consequences for their progeny. In the modern world, maternal chronodisruption can be caused by shift work, jet travel across time zones, mistimed eating, and excessive artificial light exposure at night. However, the impact of maternal chronodisruption on the developmental programming of various chronic diseases remains largely unknown. In this review, we outline the impact of light, the circadian clock, and circadian signaling pathways in pregnancy and fetal development. Additionally, we show how to induce maternal chronodisruption in animal models, examine emerging research demonstrating long-term negative implications for offspring health following maternal chronodisruption, and summarize current evidence related to light and circadian signaling pathway targeted therapies in pregnancy to prevent the development of chronic diseases in offspring.
\end{abstract}

Keywords: circadian rhythm; developmental origins of health and disease (DOHaD); developmental programming; glucocorticoid; hypertension; light; melatonin; pregnancy

\section{Introduction}

Light provides much of the information that enables organisms to adapt to their environment. When sunlight is unavailable at night and/or indoors, artificial light enables humans to see and permits productivity [1]. However, exposure to excessive and obtrusive light produced by humans at night results in light pollution [1]. Global light pollution has been increasing exponentially during the past century [1]. Light pollution can cause unintended physiological consequences. In mammals, the production of melatonin-a key player in circadian regulation — can be suppressed by light [2]. Light also activates the adrenal glands and induces a surge in glucocorticoid (GC) levels via the suprachiasmatic nucleus (SCN), part of the sympathetic nervous system [3]. Light pollution disrupts circadian rhythms by altering downstream signaling pathways and can lead to the development of a variety of chronic diseases, such as cancer, cardiovascular disease, diabetes, metabolic syndrome, and obesity [4-7]. Conversely, the use of light therapy has been evaluated in jet lag, shift work, and circadian rhythm disorders [8,9]. Further, melatonin treatment confers a number of beneficial effects to human health, including those related to cardiovascular function, blood pressure, the nervous system, and lipid and glucose metabolism [10-12]. 
Most chronic diseases originate from early life. The developing fetus, if exposed to a suboptimal environment during pregnancy, experiences alterations to normal patterns of growth and development that increase its vulnerability to a wide range of chronic diseases in later life [13]. This concept is called the developmental origins of health and disease, or $\mathrm{DOHaD}$ [14]. The developing fetal circadian system can be programmed by the external environment. However, the impact of light-related chronodisruption during pregnancy on offspring health remains poorly understood.

This review included publications on the relationship between the light and circadian signaling pathway and pregnancy and the effects on the developmental programming of chronic diseases in offspring. We searched the PubMed/MEDLINE databases for studies published in English between January 1990 and January 2020, using the following search terms: "light", "circadian rhythm", "chronodisruption", "clock gene", "melatonin", "pineal", "glucocorticoid", "developmental programming", "DOHaD", "offspring", "progeny", "cardiovascular diseases", "obesity", “hypertension", "neurological diseases", "pregnancy", "mother", "maternal", "gestation", "neonatal", "perinatal", "light therapy", "photobiomodulation", and "reprogramming.". Relevant studies were assessed for inclusion by title and abstract, followed by full-text review.

In this review, we particularly focused on the following areas: the impacts of light and circadian signals in pregnancy and fetal development; human studies for the programming of adult diseases related to maternal chronodisruption; animal models of maternal chronodisruption; mechanisms underlying maternal chronodisruption-induced programmed diseases; and targeting of the light and circadian signaling pathway as a reprogramming therapy to prevent $\mathrm{DOHaD}$-related diseases.

\section{The Impacts of Light and Circadian Signals in Pregnancy and Fetal Development}

\subsection{The Retinohypothalamic Pathway}

Light often serves as a stimulus to induce circadian clock responses. Circadian systems detect light and transform it into a timed signal that synchronizes all physiological processes to the same zeitgeber. This system is driven by the circadian clock, which is composed of an intrinsic pacemaker, the light input by photoreceptors, and output signals [15]. Circadian clocks consist of a central clock within the SCN and peripheral clocks within peripheral organs. As shown in Figure 1, there is a connection called the retinohypothalamic tract (RHT) that extends from the retina of the eye to the SCN [16]. In the presence of light, neurons of the SCN directly inhibit the neurons in the paraventricular hypothalamic nucleus (PVN) that are responsible for stimulating the pineal gland to secrete melatonin. That is, light inhibits melatonin secretion, whereas darkness allows the pineal gland to secrete melatonin [17]. Melatonin is synthesized during the dark period of the daily light:dark cycle, independent of whether the animal is diurnally or nocturnally active. The melatonin secreted by the pineal gland provides inhibitory feedback information to SCN neurons. Peripheral clocks are present in nearly every tissue and organ system (i.e., liver, heart, and kidney), which are regulated by the SCN through the autonomic nervous system (ANS) and rhythmic entraining signals (Figure 1).

There is a strong interaction between the circadian clock system and the hypothalamic-pituitary-adrenal (HPA) axis [18]. The light-activated central clock controls the HPA axis through synapses between the SCN and the PVN, thereby inducing the release of adrenal GCs. Circulating GCs act as a strong entrainment signal for peripheral circadian oscillators. GCs play a dual role as a circadian and stress signal. In the absence of stress, GC secretion displays a circadian rhythm, with rise prior to wake up. The coupling of GC secretion with activity phase onset allows GC to mediate similar physiological functions regardless of whether in diurnal species is primarily active during the day (e.g., humans) or the night in nocturnal species (e.g., rodents) [18]. On the other hand, a stressful event results in secretion of GCs. SCN uses both humoral and neuronal pathways to transmit time-related information to peripheral clocks. The rhythms of melatonin and GCs provide synchronization signals for clocks in peripheral organs. 


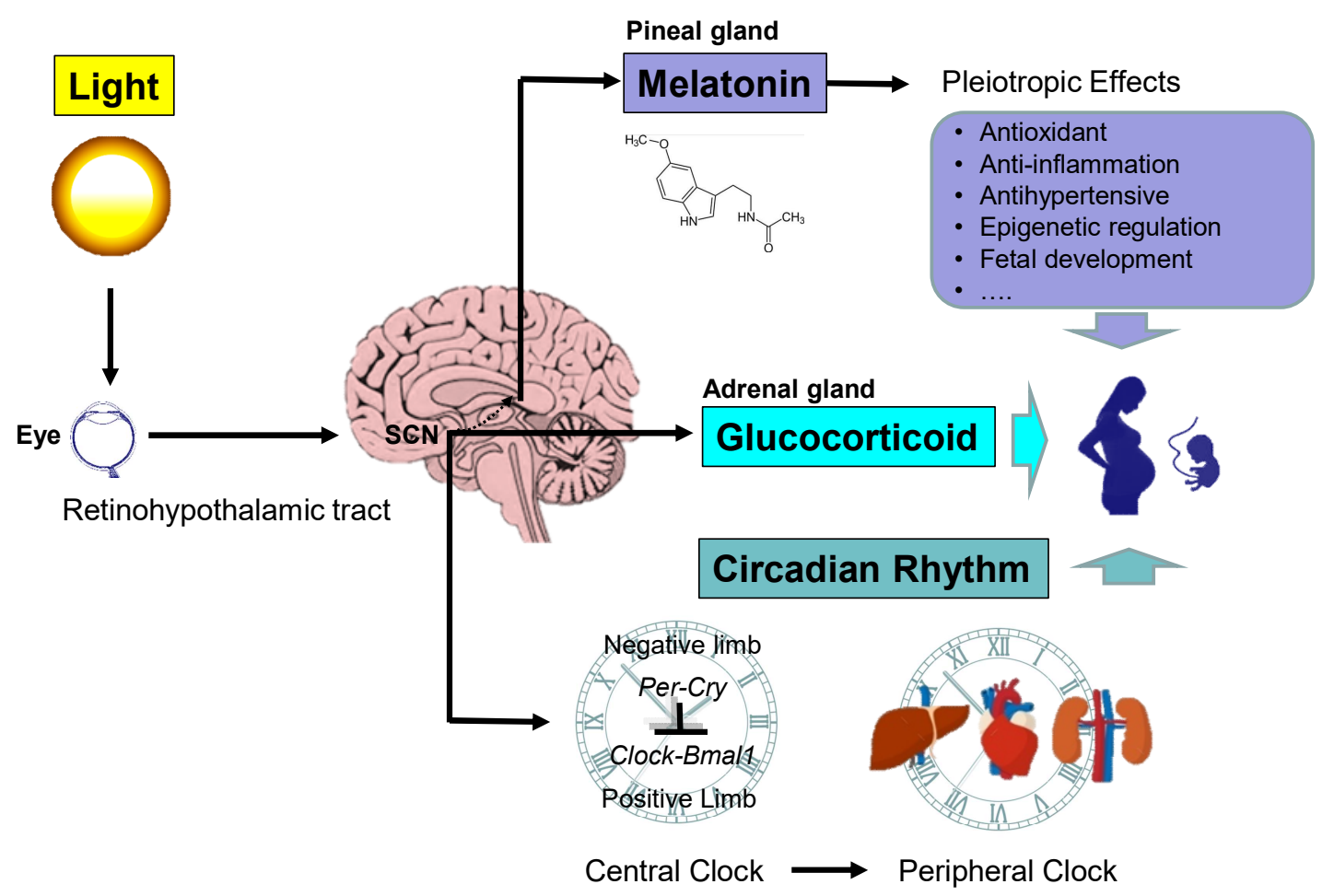

Figure 1. Schema outlining the light and circadian signaling pathway in pregnancy. The retinohypothalamic tract transmits light from the eyes to the suprachiasmatic nucleus (SCN). In the pineal gland, melatonin synthesis follows a rhythm driven by the SCN. Melatonin has pleiotropic biological function whereby it regulates pregnancy and fetal development. The SCN also stimulates the release of glucocorticoids (GCs) in the adrenal gland in a light-dependent manner. GC signaling is crucial for fetal development. The circadian clock system consists of central and peripheral clocks, which are coordinated to produce daily rhythms. The molecular mechanisms responsible for the generation of the rhythmicity within the SCN and peripheral clocks are regulated by interactive transcriptional-translational feedback loops between the clock genes, including Per1, Per1, Cry1, Cry2, CLOCK, BMAL1, Rev-erb $\alpha$, and CK1E, and their protein products. The cellular circadian clock consists of positive and negative interlinked regulatory limbs. CLOCK and BMAL1 form a heterodimer that positively activates the rhythmic expression of Per, Cry, and Rev-erb $\alpha$ genes. The negative limb includes the PER and CRY proteins. After nuclear translocation of both proteins, the PER:CRY complex interacts with the CLOCK:BMAL1 heterodimer and inhibits CLOCK:BMAL1-mediated transcription. The regulation of Bmal1 transcription is mediated mostly by REV-ERB $\alpha$. The SCN and peripheral clocks operate with similar components and share a similar molecular core clock mechanism. Circadian signals can transfer from mother to fetus. The rhythms of melatonin and GCs provide synchronization signals for peripheral clocks. The interactions between light, the circadian clock, and the circadian signals melatonin and GCs in pregnancy ultimately impact the health of the mother and offspring.

\subsection{Maternal and Fetal Circadian Rhythms}

The basic molecular core clock mechanism in cells responsible for the generation of rhythmicity within the SCN and peripheral clocks is formed by interactive transcriptional-translational feedback loops between the clock genes, namely two Per (encoding the period, Per1,2), two Cry (encoding the cryptochrome, Cry1,2), circadian 1 ocomotor output cycles kaput (CLOCK), brain and muscle aryl-hydrocarbon receptor nuclear translocator-like 1 (BMAL1), Rev-erb $\alpha$ and casein kinase 1 epsilon (CK1 1 ), and their protein products $[19,20]$. The cellular circadian clock consists of positive and negative interlinked regulatory limbs $[19,20]$. CLOCK and BMAL1 form a heterodimer and positively activate the rhythmic expression of Per, Cry, and Rev-erb $\alpha$ genes. The negative limb includes the PER and CRY proteins. After nuclear translocation of both proteins, the PER:CRY complex directly interacts with the 
CLOCK:BMAL1 heterodimer and inhibits CLOCK:BMAL1-mediated transcription. The regulation of Bmal1 transcription is mediated mostly by REV-ERB. The SCN and peripheral clocks operate with similar components and share a similar molecular core clock mechanism. Clock genes are expressed in the oocytes and in fetal organs during organogenesis, while they are not involved in circadian clock regulation in oocytes [21].

\subsection{Ontogenesis of the Circadian Clock}

In mammals, the maternal circadian clock within the SCN is entrained by photic as well as non-photic cues with the time of the day [22]. The Per 1 mRNA is upregulated by photic and downregulated by non-photic entraining stimuli. The fetal SCN and peripheral clocks are entrained via, as yet only partially recognized, rhythmically delivered maternal stimuli. Ontogenesis of the mammalian fetal SCN clock is a gradual process that occurs from the fetal to postnatal periods [23]. First, SCN neurogenesis occurs from 31 weeks of gestation in primates [24]. Second, the SCN is innervated by the RHT and is responsive to light at birth in mammals [25]. Finally, a mature mammalian circadian system displaying overt physiological rhythms slowly develops throughout the late prenatal and early postnatal period. Although the mammalian fetal clock begins to exhibit intrinsic rhythmicity in terms of molecular clockwork only around birth and early postnatally, the phase of the new formation and appearance of rhythms in the fetal SCN is set by the maternal SCN early in the prenatal period. In mammals, the development of peripheral clocks depends on the maturation of the organ housing the clock as well as the maturation of the molecular clockwork. Thus, the first appearance of molecular oscillations is highly organ-specific [23].

\subsection{Maternal Circadian Signals: Melatonin and Glucocorticoid}

Among the maternal circadian signals likely to impact fetal rhythmicity, melatonin and GCs appear to play key roles. Maternal melatonin and GCs can transverse the placenta and so they can provide temporal signals to the fetus. Maternal melatonin signals play key roles in establishing and entraining fetal circadian clocks [24]. CLOCK/BMAL1 heterodimers interact physically and acetylate glucocorticoid receptors (GRs), thereby reducing their affinity to glucocorticoid responsive elements (GREs) and their translocation into the nucleus. CRY1 and CRY2 can interact with the C-terminal domain of GR in a ligand-dependent fashion, repressing the GR-mediated transactivation of certain target genes [26]. Rhythmic GC and melatonin secretion in human infants appear at three and nine weeks of age, respectively [24,27].

\subsection{Melatonin in Pregnancy and the Fetus}

Melatonin is primarily secreted by the pineal gland at night. Tryptophan is a precursor for melatonin biosynthesis. As well as the pineal gland, melatonin can be produced in many other organs, such as the retina, skin, and bone marrow [2]. Melatonin regulates variable physiological functions through the activation of two G protein-coupled receptors, melatonin receptor-1 (MT1) and -2 (MT2) [28]. Additionally, melatonin can interact with the nuclear hormone receptor family retinoid $\mathrm{Z}$ receptor (RZR)/retinoid acid receptor (ROR) for signal transduction [28]. Melatonin has pleiotropic biological functions that control circadian rhythms, redox homeostasis, inflammation, epigenetic regulation, and fetal development [4,29-31].

\subsection{Placental Melatonin}

During human pregnancy, the placenta secretes a plethora of hormones into the maternal circulation, which modulate the mother's physiology and transfer the nutrients available to the fetus for growth [32]. Among these placental hormones, melatonin plays critical roles in driving maternal physiological adaptations and providing beneficial effects for both the mother and the fetus [33]. Placenta-derived melatonin acts as an autocrine, paracrine, and endocrine hormone in a non-circadian fashion [34]. In addition to the source of melatonin, the placental villous trophoblasts express 
melatonin receptors [33]. Placenta-derived melatonin not only acts with the MT1 and MT2 receptors but also directly scavenges free radicals, which reduce oxidative damage to placental tissues [33,34]. Maternal pineal melatonin can pass the placenta and transfer light signals to the fetus $[35,36]$. Thus, photoperiodic information perceived by the mother can be transferred to the fetus to synchronize fetal circadian rhythms via maternal melatonin rhythms [36]. Melatonin receptors are present in many areas of the human fetal brain [37]. Therefore, maternal and placental melatonin presumably play roles in the early stage of fetal development. During the neonatal period, the production of melatonin by the pineal gland is activated after birth, although it lacks the rhythmic secretion of melatonin until nine weeks of age in humans [28].

\subsection{Glucocorticoids in Pregnancy and the Fetus}

The SCN stimulates the release of GCs in a light-dependent manner, leading to a rhythmicity that peaks in the early morning just prior to lights-on and decreases throughout the day in humans [18]. The circadian GC rhythm is implicated in the coordination of clock function in central and peripheral tissues [38]. At the molecular level, the circadian clock and GCs relay on two parallel transcriptional-translational feedback loops that modulate each other [25]. The GC-GR complex binds glucocorticoid responsive elements (GREs) in the promoter region of several clock genes and various clock-controlled genes. Conversely, CLOCK/BMAL1 heterodimers that are active during the night interact physically and acetylate GR, thereby reducing its affinity to GREs and its translocation into the nucleus. Additionally, CRY1 and CRY2 can interact with the C-terminal domain of GR in a ligand-dependent fashion, repressing the GR-mediated transactivation of certain target genes. Furthermore, REV-ERB $\alpha$, which is active during the day, acts as an inhibitor of BMAL1 expression, thus stabilizing the nuclear localization of GR, reinforcing its transcriptional activity. Through this complex network of interactions, GCs and the clock machinery can mutually regulate each other. Additionally, GCs have been reported to influence melatonin production through the regulation of the nuclear factor kappa-light-chain-enhancer of activated B cells (NFKB) transcriptional program [39].

Excess or deficient GC signaling during developmental windows may disrupt the developmental trajectory of the fetus, leading to permanent negative consequences [40]. Glucocorticoid receptors (GRs) are expressed in most fetal tissues and the placenta and are crucial for survival [41]. Although gestational GC levels show a strong circadian variation, it is not translated to the embryo. Fetal GC concentrations can be maintained at a stable level due to GC being inactivated by the placental GC barrier [42]. However, in stressful situations, an excessive level of GCs can saturate this barrier and reach fetal tissues, interfering with the developmental programming of the circadian clock and stress system [43]. As a result, increased DNA methylation in the GR promoter and reduced expression of GR have been shown in the hippocampus [44]. Such epigenetic modifications have been proposed as a possible underlying mechanism for altered regulation of the HPA axis.

\section{Maternal Chronodisruption and Offspring Health}

\subsection{Human Studies for Programming of Adult Diseases Related to Maternal Chronodisruption}

Epidemiologic studies have revealed an association between gestational chronodisruption and adverse pregnancy outcomes [45-53]. The disruption of circadian rhythms in pregnant women can occur through shift work [45-47], jet travel across time zones [51,52], or exposure to light at night [48]. Several observational studies suggest that pregnant night workers might have an increased risk of miscarriage [48], hypertensive disorders of pregnancy [49], and preterm delivery [50]. Pregnant flight attendants were shown to have a higher risk of spontaneous abortion and miscarriage when compared to flight attendants who did not work during their pregnancy [51,52]. A meta-analysis of 62 studies with 196,989 women showed that working rotating shifts is associated with preterm delivery, an infant small for gestational age, preeclampsia, and gestational hypertension [53]. Additionally, an association 
between pregnant women working fixed night shifts and increased odds of preterm delivery and miscarriage was shown [53].

Nevertheless, little is known about whether maternal circadian rhythm disruption impairs offspring health in adulthood in human studies. A recent study showed that male offspring aged 9 to 16 years born to shift working mothers had higher awakening cortisol (natural GC) levels, followed by a steeper early decline and a flatter late decline (between 4 and $16 \mathrm{~h}$ after awakening) compared with those born to mothers who did not work night shifts [47]. These findings suggest that maternal rotating night shift work influences the circadian rhythm of GC secretion in young adult offspring. A case series study reported that newborns born to night workers had lower Apgar scores and breastfeeding difficulty, indicating worse outcomes [54]. Another report demonstrated that there is no association between nightshift work before or during pregnancy and mental health disorders in young adult offspring [55]. Given that only a few human studies are available on this issue and that these observational studies cannot directly establish a causal relationship between maternal chronodisruption and lifelong health in the offspring, animal models are of great importance to identify which mechanisms underlying maternal circadian disruption may influence the programming of offspring phenotypes and lead to the development of specific preventive interventions.

\subsection{Animal Models of Maternal Chronodisruption}

Table 1 summarizes various animal models utilized to investigate the relationship between maternal circadian rhythm disruption and offspring health [56-74]. Of note is that not only constant light, but also diurnal light deficiency and/or continuous darkness, are disruptive for the circadian system. Several conditions related to diurnal light deficiency, such as living at high latitudes [75] and vitamin D deficiency [76], have been linked to chronodisruption. Additionally, serotonin, the precursor of melatonin, was reported to adjust circadian rhythms through serotonergic afferents [77]. In the current review, we mainly focused on the commonly used animal models for studying maternal chronodisruption, and, for the sake of brevity, we have restricted the presented data to constant light, chronic photoperiod shift, pinealectomy, and glucocorticoid exposure.

The most commonly used animal species include rodents, sheep, and pigs. Light is known to promote sleep in nocturnal species and alertness in day-active animals. Thus, nocturnal (e.g., rodents) and diurnal (e.g., sheep and pigs) animals might differ in their temporal activity patterns and their circadian systems in response to constant light (or constant dark) exposure. As light is the principal environmental signal for the circadian system, exposing an animal to continuous constant light can disrupt the SCN-based clock and produce arrhythmic patterns of running-wheel activity. Adult offspring exposed to constant light prenatally have been reported to have an increased risk for developing hypertension [56], altered behaviors [57], and impaired cognition function [58]. These adverse outcomes are related to dysregulated melatonin signaling [57] and hippocampal clock gene expression [58]. Another approach is chronic photoperiod shift (CPH). Chronic phase shifts of the photoperiod throughout pregnancy programs adult offspring to display impaired endocrine, cardiovascular, and metabolic function [59,60]. Additionally, CPH during pregnancy has been reported to induce behavior changes characterized as hyperactivity and social avoidance in young adult rats [61]. Furthermore, gestational $\mathrm{CPH}$ has been reported to disrupt the peripheral liver clock [62]. Maternal pinealectomy results in melatonin deficiency in pregnant mothers. This model can cause negative outcomes in reproductive [63], neuropsychiatric [64], and metabolic function in adult offspring [65]. Finally, in utero exposure to the synthetic GC analogs dexamethasone (DEX) or betamethasone has been shown to induce chronodisruption as well as a wide range of adult diseases. Prenatal DEX exposure was reported to induce arrhythmic glucocorticoid secretion and an absence of circadian oscillations in hippocampal clock gene expression in adult offspring [66]. Moreover, antenatal GC exposure is related to hypertension [67,73], liver steatosis [69,72], hippocampal lesions [70], kidney disease [71,73], obesity [72], and an impaired HPA axis [74]. Although SCN ablation [78], timed food access [79], and genetic manipulation (e.g., CLOCK mutant mice) [80] have 
been employed to disrupt circadian rhythms in pregnant animals, their long-term effects on offspring have not been studied yet. To sum up, programming effects of maternal chronodisruption have been reported in rodents ranging from 1 week to 12 months of age, which is roughly equivalent to human ages from infancy to middle adulthood. However, future studies into the long-term offspring outcomes of maternal circadian disruption are still urgently warranted. The associations between maternal chronodisruption and the risks for many adult diseases are illustrated in Figure 2.

Table 1. Commonly used animal models for studying the impacts of maternal chronodisruption on offspring health.

\begin{tabular}{|c|c|c|}
\hline Model & Technique & Impacts on Offspring Health \\
\hline Constant light & $\begin{array}{l}\text { 24-h constant light exposure } \\
\text { during pregnancy }\end{array}$ & $\begin{array}{l}\text { Induced hypertension in 12-week-old rat offspring [56] } \\
\text { Induced behavior changes and melatonin signaling dysregulation in 90-day-old rat } \\
\text { offspring [57] } \\
\text { Impaired cognition function and altered hippocampal clock gene expression in } \\
\text { 90-day-old rat offspring [58] }\end{array}$ \\
\hline Chronic photoperiod shift & $\begin{array}{l}\text { Repeated photoperiod shifts } \\
\text { during pregnancy }\end{array}$ & $\begin{array}{l}\text { Induced hyperinsulinemia and insulin intolerance in 12-month-old female rat } \\
\text { offspring [59] } \\
\text { Altered endocrine, cardiovascular, and metabolic function in 90-day-old rat offspring [60] } \\
\text { Induced behavior changes with hyperactivity and social avoidance in 60-day-old rat } \\
\text { offspring [61] } \\
\text { Disrupted daily rhythms in hepatic clock genes in 3-month-old rat offspring [62] }\end{array}$ \\
\hline Pinealectomy & Surgical removal of pineal gland & $\begin{array}{l}\text { Altered seasonal variations of reproductive hormones in 60-day-old rat offspring [63] } \\
\text { Increased depressive-like responses in adult swine offspring [64] } \\
\text { Induced glucose intolerance in 18-week-old rat offspring [65] }\end{array}$ \\
\hline \multirow[t]{2}{*}{ Glucocorticoid exposure } & Prenatal dexamethasone treatment & $\begin{array}{l}\text { Induced depression-like behavior, arrhythmic glucocorticoid secretion, and absent } \\
\text { circadian oscillations in hippocampal clock gene expression in 12-month-old mice } \\
\text { offspring [66] } \\
\text { Altered clock genes in adipose tissue and enhanced obesity, insulin dysregulation, and } \\
\text { hypertension in 6-month-old rat offspring [67] } \\
\text { Induced hypertension in 16-week-old rat offspring [68] } \\
\text { Induced liver steatosis in 7-day-old offspring [69] } \\
\text { Altered hippocampal morphology in 16-week-old rat offspring [70] } \\
\text { Altered transcriptome in 16-week-old offspring kidney [71] }\end{array}$ \\
\hline & Prenatal betamethasone treatment & $\begin{array}{l}\text { Induced obesity and liver steatosis in 10-year-old baboons [72] } \\
\text { Induced hypertension and renal dysfunction in 1.5-year-old sheep [73] } \\
\text { Altered hippocampal expression of HPA-related genes in 3.5-year-old sheep [74] }\end{array}$ \\
\hline
\end{tabular}

Studies tabulated according to animal models and techniques. HPA: hypothalamic-pituitary-adrenal.
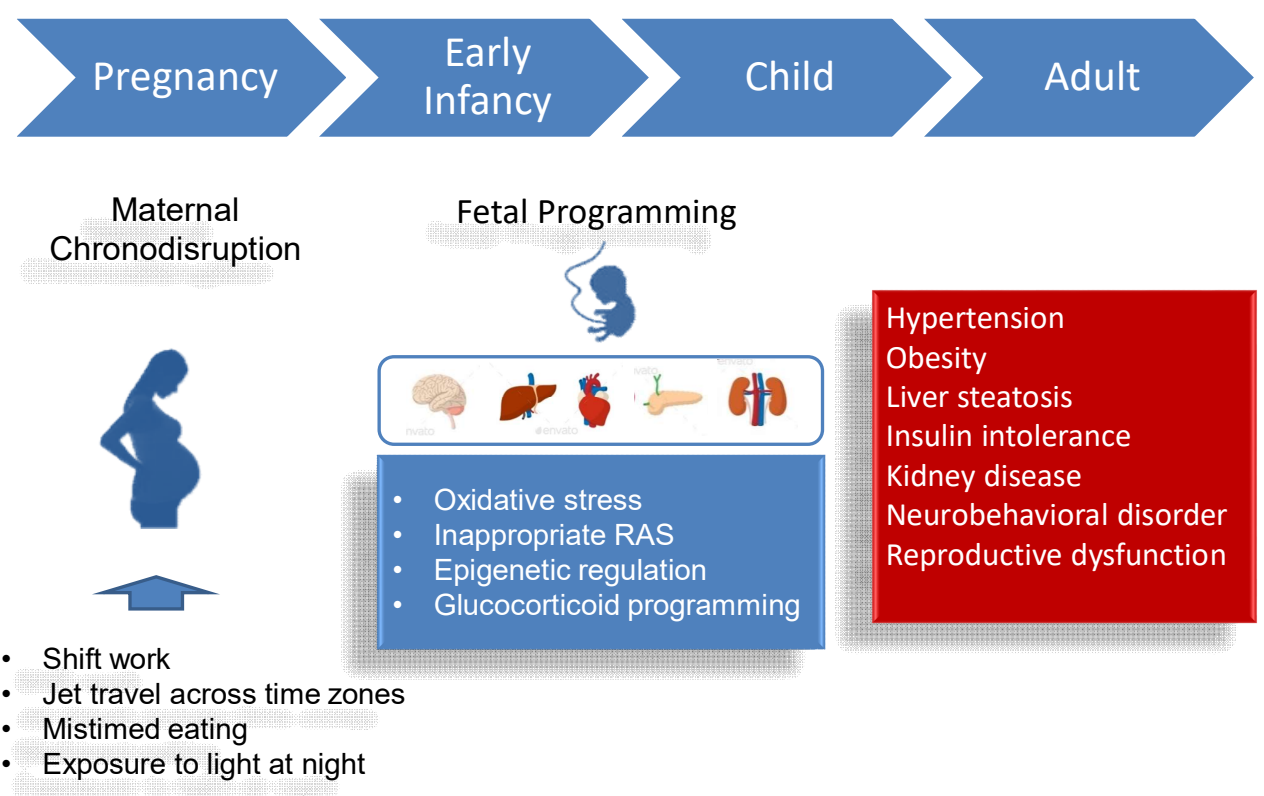

Hypertension

Obesity

Liver steatosis

Insulin intolerance

Kidney disease

Neurobehavioral disorder

Reproductive dysfunction

- Shift work

- Jet travel across time zones

- Mistimed eating

- Exposure to light at night

Figure 2. Schematic illustration of the association between maternal chronodisruction, fetal programming, and increased vulnerability to many adult disease. 


\subsection{Mechanisms Underlying Maternal Chronodisruption-Induced Programmed Diseases}

So far, the common mechanisms involved in the developmental programming of adult chronic diseases remain undetermined. However, emerging evidence has provided crucial insight into the pathways involved, including oxidative stress [81,82], inappropriate activation of the renin-angiotensin system (RAS) [83], epigenetic regulation [84], and glucocorticoid programming [40,85] (Figure 2). Notably, extensive experimental animal studies have demonstrated interplay between circadian rhythm disruption and the above-mentioned mechanisms [86-89].

First, the fetus is not sufficient to overcome reactive oxygen species (ROS) overproduction, due to its low-antioxidant capacity. In response to adverse in utero environments, the development of the fetus is thus vulnerable to oxidative stress damage [82,90]. Melatonin is not only a hallmark of circadian rhythm functionality but is also a natural antioxidant [91]. Thus, there is a close inter-relationship between oxidative stress and chronodisruption via melatonin signaling in a variety of diseases. As we previously reviewed [81], various early-life insults enable the induction of developmental programming linked to oxidative stress, such as maternal undernutrition [92], maternal diabetes [93,94], maternal exposure to ethanol [95], maternal inflammation [96], glucocorticoid exposure [68,97], preeclampsia [98], prenatal hypoxia [99], and a maternal high methyl-donor diet [100]. Conversely, maternal melatonin therapy showed a protective role that reverses the programming processes in models of maternal caloric restriction [92], $\mathrm{N}^{\mathrm{G}}$-nitro-L-arginine-methyl ester (L-NAME) induced preeclampsia [98], a maternal high-fructose diet [101], a maternal high methyl-donor diet [100], and prenatal DEX exposure [70]. Considering the interplay between melatonin and oxidative stress, targeting circadian melatonin signals to counteract oxidative stress and protect against adult diseases of developmental origin, deserves further elucidation.

Secondly, RAS is a well-known hormonal cascade that controls kidney development and blood pressure [102]. In humans, circulating renin, angiotensin (Ang) II, and aldosterone rhythms have an acrophase in early morning [87]. In nocturnal rat species, the activity of the RAS also has a circadian rhythm, with a diurnal acrophase [103]. In melatonin-deficient hypertension [104], the classical angiotensin-converting enzyme (ACE)-Ang II-angiotensin type 1 receptor (AT1R) axis is activated. In the constant light exposure model, the development of hypertension in adult rat offspring is related to activation of the RAS [56]. Various adverse conditions in utero have been reported to activate the classical RAS axis, resulting in renal programming and consequent hypertension in later life $[105,106]$. Apart from the classical RAS axis, the ACE2-angiotensin (1-7)-Mas receptor axis is also involved in developmental programming [107], by opposing many actions of Ang II on AT1R. Gestational melatonin use has been reported to block the activation of the classical RAS cascade and prevent the development of hypertension in adult offspring in several animal models, including maternal constant light exposure [56,108] and the prenatal GC exposure model [68]. On the other hand, maternal melatonin therapy can activate the ACE2-angiotensin (1-7)-MAS axis by the induction of renal Agtr1b and Mas1 expression to prevent hypertension in adult male offspring programmed by prenatal GC exposure plus post-weaning from a high-fat diet [109]. Therefore, the results from these studies suggest that RAS may be an underlying mechanism involved in hypertension programmed by maternal circadian rhythm disruption.

Third are studies of crosstalk between circadian rhythms and epigenetic regulation [88]. Epigenetic mechanisms such as post-translational modification of histones, DNA methylation, and RNA interference play key roles in gene regulation [30]. Histone modifications, including acetylation-deacetylation and methylation-demethylation, are involved in regulating the expression of transcription factors of Clock genes [88,110]. Interestingly, CLOCK possesses histone acetyltransferase activity [111]. On the other hand, many epigenetic modification enzymes are rhythmically expressed [88]. Thus, these observations support the view that the circadian clock can directly regulate epigenetic modification enzymes and that these enzymes, in turn, contribute feedback to the circadian clock, contributing to the mutual regulation of oscillators. On the other hand, the circadian signal melatonin is also involved in epigenetic regulation. In a prenatal GC 
model [70], maternal melatonin therapy restored reelin mRNA expression levels by reducing DNA methyltransferase 1 (DNMT1) expression. Additionally, melatonin and trichostatin A (a histone deacetylase [HDAC] inhibitor) have similar beneficial effects on hypertension programmed by GC exposure [112], suggesting that melatonin acts as a HDAC inhibitor. These observations support the view that epigenetic regulation may contribute to the development of hypertension programmed by maternal circadian rhythm disruption.

Last, emerging evidence supports the interplay between glucocorticoid programming and chronodisruption on developmental programming [85,89]. A developing fetus is prone to exposure to excessive glucocorticoids through exogenous administration (e.g., preterm birth) or through excess maternal corticosteroids (e.g., stressed pregnancies). The HPA axis is particularly susceptible to developmental programming by GCs, impairing a variety of organ systems, such as the kidneys [68,71,72], liver [69,72], central nervous system [70], and endocrine system [72,74]. As rhythmic GCs coordinate central and peripheral clocks, prenatal GC exposure-induced obesity and hypertension are relevant to altered clock genes in peripheral tissues [67]. Conversely, melatonin use in pregnancy has been reported to protect prenatal GC-induced programming of hypertension [113] and cognition deficit [70].

\section{Targeting on Light and Circadian Signaling Pathway as a Reprogramming Therapy}

\subsection{Light and Circadian Signaling-Related Therapy in Human Diseases}

Light therapy has been evaluated in healthy individuals undergoing shift work, jet travel, and space flights $[8,9]$. Although lighting based on light-emitting diodes has the potential to improve human health [114], its clinical application for specific human diseases still has a long way to go. Photobiomodulation (PBM) uses low levels of visible or near-infrared light to heal and stimulate tissue [115]. So far, PBM has been applied to treat several human diseases such as stroke, Parkinson's disease, Alzheimer's disease, traumatic brain injury, and psychiatric disorders [115]. Although there have been some studies relevant to light therapy $[116,117]$ in pregnancy, none of them have focused on offspring outcomes in adulthood. In the area of complementary and alternative medicine, several suggested therapies for insomnia might be applied for treating chronodisruption, despite not yet being recommended as standard therapies [118]. These therapies include herbal medicine, acupuncture, acupressure, aromatherapy, foot reflexology, music therapy, and yoga. Four herbal medicines—valerian, chamomile, kava, and wuling-have been examined regarding their clinical efficiency for insomnia in a meta-analysis study, while there is insufficient evidence to support the use of herbal medicine for insomnia [119]. So far, whether complementary and alternative medicines can be applied in maternal chronodisruption to improve offspring outcomes remains largely unknown.

Furthermore, circadian melatonin signaling has been used to treat a variety of human diseases [11,120-122]. Oral melatonin dosages ranging from 0.3 to $1600 \mathrm{mg}$ daily have been reported to be relatively safe for humans. [123]. Although emerging evidence from animal models of developmental programming suggests that melatonin use in pregnancy and lactation has reprogramming effects that prevent $\mathrm{DOHaD}$-related disorders [31,124], no clinical trials of melatonin in pregnant women have been conducted to assess its use and safety. Another circadian signal, GC, has been well used in human diseases. Antenatal GC intake is recommended to accelerate fetal lung maturation. Nevertheless, prenatal GC intake induces many long-term negative outcomes that greatly influence its therapeutic potential in $\mathrm{DOHaD}$-related disorders.

\subsection{Melatonin as a Reprogramming Therapy in Animal Models}

While current medical treatment focuses on high-risk individuals in adulthood, DOHaD concepts offer a "reprogramming"' strategy to prevent the development of adult diseases during early life [125]. So far, melatonin seems to be the only reprogramming therapy that is likely to catch the attention of researchers. The overview of experimental studies in Table 2 illustrates data documenting the 
reprogramming effects of melatonin treatment in the pregnancy and/or lactation period in animal studies. We only considered studies reporting offspring outcomes starting from childhood in the present review.

As shown in Table 2, rodents have been the dominant animal species used. Various developmental programming models have been examined, including maternal caloric restriction [92], L-NAME induced preeclampsia [98], a maternal high-fructose diet [101], maternal hyperhomocysteinemia [126], maternal phenytoin exposure [127], a maternal high-fructose diet plus a post-weaning high-salt diet [128], maternal constant light exposure [56,108], a maternal high methyl-donor diet [100], prenatal GC exposure $[69,112,129,130]$, and maternal hypermethioninemia [131]. These environmental insults lead to adverse offspring outcomes including cognition deficits [126], neurobehavioral dysfunction [106,127], hypertension [56,92,98,100,101,113], and liver steatosis [129,130]. All of these adverse offspring phenotypes can be prevented, or at least moderated, by maternal melatonin treatment. It is notable that melatonin has pleiotropic biological functions in pregnancy; these beneficial reprogramming effects might not be directly attributed to its regulation of the circadian rhythm [35]. Therefore, additional studies are warranted to elucidate the underlying mechanisms of melatonin and determine appropriate therapeutic windows and ideal doses of melatonin before clinical translation.

Table 2. Reprogramming effects prevented by melatonin.

\begin{tabular}{|c|c|c|}
\hline Animal Models & Route of Administration & Reprogramming Effects \\
\hline Maternal caloric restriction & Drinking water & Prevented hypertension in 12-week-old rat offspring [92] \\
\hline Maternal L-NAME exposure & Drinking water & Prevented hypertension in 12-week-old rat offspring [98] \\
\hline Maternal high-fructose diet & Drinking water & Prevented hypertension in 12-week-old rat offspring [101] \\
\hline Maternal hyperhomocysteinemia & Subcutaneous injection & Prevented cognition deficit in 75-day-old rat offspring [126] \\
\hline Maternal phenytoin exposure & Drinking water & Protected neurobehavioral dysfunctions in 12-week-old rat offspring [127] \\
\hline \multirow{2}{*}{ Maternal constant light exposure } & Drinking water & Prevented hypertension in 12-week-old rat offspring [56] \\
\hline & Drinking water & Protected anxiety-like and sexual behaviors in 16-week-old rat offspring [106] \\
\hline Maternal high methyl-donor diet & Drinking water & $\begin{array}{l}\text { Attenuated hypertension and altered renal transcriptome in 12-week-old rat } \\
\text { offspring [100] }\end{array}$ \\
\hline $\begin{array}{l}\text { Maternal high-fructose diet plus } \\
\text { post-weaning high-salt diet }\end{array}$ & Drinking water & Attenuated hypertension in 12-week-old rat offspring [128] \\
\hline \multirow{3}{*}{ Prenatal GC exposure } & Drinking water & Protected hippocampal morphology in 16-week-old rat offspring [70] \\
\hline & Drinking water & $\begin{array}{l}\text { Prevented hypertension and increased nephron number in 16-week-old rat } \\
\text { offspring [113] }\end{array}$ \\
\hline & Drinking water & Protected liver steatosis in 16-week-old rat offspring [129] \\
\hline $\begin{array}{l}\text { Prenatal GC exposure plus } \\
\text { post-weaning high-fat diet }\end{array}$ & Drinking waterDrinking water & $\begin{array}{l}\text { Prevented hypertension in 16-week-old rat offspring [109] } \\
\text { Protected liver steatosis in 6-month-old rat offspring [130] }\end{array}$ \\
\hline Maternal hypermethioninemia & Subcutaneous injection & Protected impaired recognition and neurons in 30-day-old rat offspring [131] \\
\hline
\end{tabular}

\section{Conclusions}

This review highlights the importance of considering environmental light and maternal circadian rhythms during pregnancy. Given the increasing incidence of shift work, jet travel across time zones, and mistimed eating in our modern society, large numbers of pregnant women are exposed to adverse environmental conditions. These suboptimal maternal conditions have implications for the developing fetus. Maternal chronodisruption affects not only central and peripheral circadian clocks but also a range of endogenous circadian signals including melatonin and GC secretion. Despite most programming effects and reprogramming approaches being examined in animal models, these observations have important translational applications, as they open a new avenue for testing the prevention of adult disease by targeting light and circadian signaling pathways in pregnant women with disrupted circadian rhythms.

Author Contributions: C.-N.H. contributed to concept generation, data interpretation, drafting of the manuscript, critical revision of the manuscript, and approval of the article; Y.-L.T. contributed to concept generation, data interpretation, critical revision of the manuscript, and approval of the article. All authors have read and agreed to the published version of the manuscript. 
Acknowledgments: This work was supported by the Grant MOST 107-2314-B-182-045-MY3 from Ministry of Science and Technology, Taiwan, and the Grants CMRPG8J0251 and CMRPG8J0891 from Chang Gung Memorial Hospital, Kaohsiung, Taiwan.

Conflicts of Interest: The authors declare no conflict of interest.

$\begin{array}{ll}\text { Abbreviations } \\ \text { ACE } & \text { Angiotensin-converting enzyme } \\ \text { AT1R } & \text { Angiotensin type 1 receptor } \\ \text { BMAL1 } & \begin{array}{l}\text { Brain and muscle aryl-hydrocarbon receptor nuclear } \\ \text { translocator-like 1 }\end{array} \\ \text { CLOCK } & \text { Circadian locomotor output cycles kaput } \\ \text { CPH } & \text { Chronic photoperiod shift } \\ \text { DEX } & \text { Dexamethasone } \\ \text { DNMT } & \text { DNA methyltransferases } \\ \text { DOHaD } & \text { Developmental origins of health and disease } \\ \text { GC } & \text { Glucocorticoid } \\ \text { HDAC } & \text { Histone deacetylase } \\ \text { HPA } & \text { Hypothalamic-pituitary-adrenal } \\ \text { L-NAME } & \text { NG-nitro-L-arginine-methyl ester } \\ \text { MT } & \text { Melatonin receptor } \\ \text { PBM } & \text { Photobiomodulation } \\ \text { RAS } & \text { Renin-angiotensin system } \\ \text { RHT } & \text { Retinohypothalamic tract } \\ \text { ROS } & \text { Reactive oxygen species } \\ \text { SCN } & \text { Suprachiasmatic nucleus }\end{array}$

\section{References}

1. Tsao, J.Y.; Han, J.; Haitz, R.H.; Pattison, P.M. The blue LED Nobel prize: Historical context, current scientific understanding, human benefit. Ann. Phys. 2015, 527, A53-A61. [CrossRef]

2. Hardeland, R.; Pandi-Perumal, S.R.; Cardinali, D.P. Melatonin. Int. J. Biochem. Cell Biol. 2006, 38, $313-316$. [CrossRef] [PubMed]

3. Ishida, A.; Mutoh, T.; Ueyama, T.; Bando, H.; Masubuchi, S.; Nakahara, D.; Tsujimoto, G.; Okamura, H. Light activates the adrenal gland: Timing of gene expression and glucocorticoid release. Cell Metab. 2005, 2, 297-307. [CrossRef]

4. Scheer, F.A.; Hilton, M.F.; Mantzoros, C.S.; Shea, S.A. Adverse metabolic and cardiovascular consequences of circadian misalignment. Proc. Natl. Acad. Sci. USA 2009, 106, 4453-4458. [CrossRef] [PubMed]

5. Stevens, R.G.; Brainard, G.C.; Blask, D.E.; Lockley, S.W.; Motta, M.E. Breast cancer and circadian disruption from electric lighting in the modern world. CA Cancer J. Clin. 2014, 64, 207-218. [CrossRef]

6. Leproult, R.; Holmbäck, U.; Van Cauter, E. Circadian misalignment augments markers of insulin resistance and inflammation, independently of sleep loss. Diabetes 2014, 63, 1860-1869. [CrossRef]

7. Morris, C.J.; Purvis, T.E.; Mistretta, J.; Scheer, F.A. Effects of the internal circadian system and circadian misalignment on glucose tolerance in chronic shift workers. J. Clin. Endocrinol. Metab. 2016, 101, 1066-1074. [CrossRef]

8. Wirz-Justice, A.; Benedetti, F.; Terman, M.; Basel, S. Chronotherapeutics for affective disorders: A clinician's manual for light and wake therapy. Ann. Clin. Psychiatry 2010, 22, 67.

9. Brainard, G.C.; Barger, L.K.; Soler, R.R.; Hanifin, J.P. The development of lighting countermeasures for sleep disruption and circadian misalignment during spaceflight. Curr. Opin. Pulm. Med. 2016, 22, 535-544. [CrossRef]

10. Hardeland, R.; Tan, D.X.; Reiter, R.J. Kynuramines, metabolites of melatonin and other indoles: The resurrection of an almost forgotten class of biogenic amines. J. Pineal Res. 2009, 47, 109-126. [CrossRef]

11. Chen, Y.C.; Tain, Y.L.; Sheen, J.M.; Huang, L.T. Melatonin utility in neonates and children. J. Formos. Med. Assoc. 2012, 111, 57-66. [CrossRef] [PubMed] 
12. Reiter, R.J.; Mayo, J.C.; Tan, D.X.; Sainz, R.M.; Alatorre-Jimenez, M.; Qin, L. Melatonin as an antioxidant: Under promises but over delivers. J. Pineal Res. 2016, 61, 253-278. [CrossRef] [PubMed]

13. Barker, D.J. The origins of the developmental origins theory. J. Intern. Med. 2007, 261, 412-417. [CrossRef]

14. Haugen, A.C.; Schug, T.T.; Collman, G.; Heindel, J.J. Evolution of DOHaD: The impact of environmental health sciences. J. Dev. Orig. Health Dis. 2015, 6, 55-64. [CrossRef] [PubMed]

15. Takahashi, J.S. Transcriptional architecture of the mammalian circadian clock. Nat. Rev. Genet. 2017, 18, 164-179. [CrossRef] [PubMed]

16. Berson, D.M.; Dunn, F.A.; Takao, M. Phototransduction by retinal ganglion cells that set the circadian clock. Science 2002, 295, 1070-1073. [CrossRef] [PubMed]

17. Lewy, A.J.; Wehr, T.A.; Goodwin, F.K.; Newsome, D.A.; Markey, S.P. Light suppresses melatonin secretion in humans. Science 1980, 210, 1267-1269. [CrossRef]

18. Spencer, R.L.; Chun, L.E.; Hartsock, M.J.; Woodruff, E.R. Glucocorticoid hormones are both a major circadian signal and major stress signal: How this shared signal contributes to a dynamic relationship between the circadian and stress systems. Front. Neuroendocrinol. 2018, 49, 52-71. [CrossRef]

19. Gumz, M.L. Molecular origin of the kidney clock. Kidney Int. 2014, 86, 873-874. [CrossRef]

20. Bonny, O.; Vinciguerra, M.; Gumz, M.L.; Mazzoccoli, G. Molecular bases of circadian rhythmicity in renal physiology and pathology. Nephrol. Dial. Transpl. 2013, 28, 2421-2431. [CrossRef]

21. Seron-Ferre, M.; Valenzuela, G.J.; Torres-Farfan, C. Circadian clocks during embryonic and fetal development. Birth Defects Res. C Embryo Today 2007, 81, 204-214. [CrossRef] [PubMed]

22. Weinert, D. Ontogenetic development of the mammalian circadian system. Chronobiol. Int. 2005, 22, 179-205. [CrossRef] [PubMed]

23. Sumová, A.; Bendová, Z.; Sládek, M.; El-Hennamy, R.; Laurinová, K.; Jindráková, Z.; Illnerová, H. Setting the biological time in central and peripheral clocks during ontogenesis. FEBS Lett. 2006, 580, 2836-2842. [CrossRef] [PubMed]

24. Torres-Farfan, C.; Rocco, V.; Monso', C.; Valenzuela, F.J.; Campino, C.; Germain, A.; Torrealba, F.; Valenzuela, G.J.; Seron-Ferre, M. Maternal melatonin effects on clock gene expression in a nonhuman primate fetus. Endocrinology 2006, 147, 4618-4626. [CrossRef]

25. Astiz, M.; Oster, H. Perinatal Programming of Circadian Clock-Stress Crosstalk. Neural Plast. 2018, 2018, 5689165. [CrossRef]

26. Vermes, I.; Dohanics, J.; Tóth, G.; Pongrácz, J. Maturation of the circadian rhythm of the adrenocortical functions in human neonates and infants. Horm. Res. Paediatr. 1980, 12, 237-244. [CrossRef]

27. Rivkees, S.A.; Hofman, P.L.; Fortman, J. Newborn primate infants are entrained by low intensity lighting. Proc. Natl. Acad. Sci. USA 1997, 94, 292-297. [CrossRef]

28. Kennaway, D.J.; Stamp, G.E.; Goble, F.C. Development of melatonin production in infants and the impact of prematurity. J. Clin. Endocrinol. Metab. 1992, 75, 367-369.

29. Ekmekcioglu, C. Melatonin receptors in humans: Biological role and clinical relevance. Biomed. Pharmacother. 2006, 60, 97-108. [CrossRef]

30. Korkmaz, A.; Reiter, R.J. Epigenetic regulation: A new research area for melatonin? J. Pineal Res. 2008, 44, 41-44. [CrossRef]

31. Tain, Y.L.; Huang, L.T.; Hsu, C.N. Developmental Programming of Adult Disease: Reprogramming by Melatonin? Int. J. Mol. Sci. 2017, 18, 426. [CrossRef] [PubMed]

32. Napso, T.; Yong, H.E.J.; Lopez-Tello, J.; Sferruzzi-Perri, A.N. The Role of Placental Hormones in Mediating Maternal Adaptations to Support Pregnancy and Lactation. Front. Physiol. 2018, 9, 1091. [CrossRef] [PubMed]

33. Soliman, A.; Lacasse, A.A.; Lanoix, D.; Sagrillo-Fagundes, L.; Boulard, V.; Vaillancourt, C. Placental melatonin system is present throughout pregnancy and regulates villous trophoblast differentiation. J. Pineal Res. 2015, 59, 38-46. [CrossRef] [PubMed]

34. Lanoix, D.; Beghdadi, H.; Lafond, J.; Vaillancourt, C. Human placental trophoblasts synthesize melatonin and express its receptors. J. Pineal Res. 2008, 45, 50-60. [CrossRef]

35. Reiter, R.J.; Tan, D.X.; Korkmaz, A.; Rosales-Corral, S.A. Melatonin and stable circadian rhythms optimize maternal, placental and fetal physiology. Hum. Reprod. Update 2014, 20, 293-307. [CrossRef]

36. Okatani, Y.; Okamoto, K.; Hayashi, K.; Wakatsuki, A.; Tamura, S.; Sagara, Y. Maternal-fetal transfer of melatonin in pregnant women near term. J. Pineal Res. 1998, 25, 129-134. [CrossRef] 
37. Seron-Ferre, M.; Torres-Farfan, C.; Forcelledo, M.L.; Valenzuela, G.J. The development of circadian rhythms in the fetus and neonate. Semin. Perinatol. 2001, 25,363-370. [CrossRef]

38. Wu, Y.H.; Zhou, J.N.; Balesar, R.; Unmehopa, U.; Bao, A.; Jockers, R.; Van Heerikhuize, J.; Swaab, D.F. Distribution of MT1 melatonin receptor immunoreactivity in the human hypothalamus and pituitary gland: Colocalization of MT1 with vasopressin, oxytocin, and corticotropin-releasing hormone. J. Comp. Neurol. 2006, 499, 897-910. [CrossRef]

39. da Silveira Cruz-Machado, S.; Tamura, E.K.; Carvalho-Sousa, C.E.; Rocha, V.A.; Pinato, L.; Fernandes, P.A.C.; Markus, R.P. Daily corticosterone rhythm modulates pineal function through NFkB-related gene transcriptional program. Sci. Rep. 2017, 7, 2091. [CrossRef]

40. Balsalobre, A.; Brown, S.A.; Marcacci, L.; Tronche, F.; Kellendonk, C.; Reichardt, H.M.; Schütz, G.; Schibler, U. Resetting of circadian time in peripheral tissues by glucocorticoid signaling. Science 2000, 289, 2344-2347. [CrossRef]

41. Moisiadis, V.G.; Matthews, S.G. Glucocorticoids and fetal programming part 1: Outcomes. Nat. Rev. Endocrinol. 2014, 10, 391-402. [CrossRef] [PubMed]

42. Cole, T.J.; Blendy, J.A.; Monaghan, A.P.; Krieglstein, K.; Schmid, W.; Aguzzi, A.; Fantuzzi, G.; Hummler, E.; Unsicker, K.; Schütz, G. Targeted disruption of the glucocorticoid receptor gene blocks adrenergic chromaffin cell development and severely retards lung maturation. Genes Dev. 1995, 9, 1608-1621. [CrossRef] [PubMed]

43. Wharfe, M.D.; Mark, P.J.; Waddell, B.J. Circadian variation in placental and hepatic clock genes in rat pregnancy. Endocrinology 2011, 152, 3552-3560. [CrossRef] [PubMed]

44. Navailles, S.; Zimnisky, R.; Schmauss, C. Expression of glucocorticoid receptor and early growth response gene 1 during postnatal development of two inbred strains of mice exposed to early life stress. Dev. Neurosci. 2010, 32, 139-148. [CrossRef]

45. Chau, Y.M.; West, S.; Mapedzahama, V. Night work and the reproductive health of women: An integrated literature review. J. Midwifery Womens Health 2014, 59, 113-126. [CrossRef]

46. Bonzini, M.; Palmer, K.T.; Coggon, D.; Carugno, M.; Cromi, A.; Ferrario, M.M. Shift work and pregnancy outcomes: A systematic review with meta-analysis of currently available epidemiological studies. Int. J. Obstet. Gynaecol. 2011, 118, 1429-1437. [CrossRef]

47. Strohmaier, S.; Devore, E.E.; Huang, T.; Vetter, C.; Eliassen, A.H.; Rosner, B.; Okereke, O.I.; Austin, S.B.; Schernhammer, E.S. Maternal rotating night shift work before pregnancy and offspring stress markers. Physiol. Behav. 2019, 207, 185-193. [CrossRef]

48. Begtrup, L.M.; Specht, I.O.; Hammer, P.E.C.; Flachs, E.M.; Garde, A.H.; Hansen, J.; Hansen, Å.M.; Kolstad, H.A.; Larsen, A.D.; Bonde, J.P. Night work and miscarriage: A Danish nationwide register-based cohort study. Occup. Environ. Med. 2019, 76, 302-308. [CrossRef]

49. Suzumori, N.; Ebara, T.; Matsuki, T.; Yamada, Y.; Kato, S.; Omori, T.; Saitoh, S.; Kamijima, M.; Sugiura-Ogasawara, M. Japan Environment \& Children's Study Group. Effects of long working hours and shift work during pregnancy on obstetric and perinatal outcomes: A large prospective cohort study-Japan Environment and Children's Study. Birth 2019, 47, 67-79. [CrossRef]

50. Davari, M.H.; Naghshineh, E.; Mostaghaci, M.; Mirmohammadi, S.J.; Bahaloo, M.; Jafari, A.; Mehrparvar, A.H. Shift Work Effects and Pregnancy Outcome: A Historical Cohort Study. J. Fam. Reprod. Health 2018, 12, 84-88.

51. Aspholm, R.; Lindbohm, M.L.; Paakkulainen, H.; Taskinen, H.; Nurminen, T.; Tiitinen, A. Spontaneous abortions among Finnish flight attendants. J. Occup. Environ. Med. 1999, 41, 486-491. [CrossRef] [PubMed]

52. Cone, J.E.; Vaughan, L.M.; Huete, A.; Samuels, S.J. Reproductive health outcomes among female flight attendants: An exploratory study. J. Occup. Environ. Med. 1998, 40, 210-216. [CrossRef] [PubMed]

53. Cai, C.; Vandermeer, B.; Khurana, R.; Nerenberg, K.; Featherstone, R.; Sebastianski, M.; Davenport, M.H. The impact of occupational shift work and working hours during pregnancy on health outcomes: A systematic review and meta-analysis. Am. J. Obstet. Gynecol. 2019, 221, 563-576. [CrossRef] [PubMed]

54. Nehme, P.A.; Amaral, F.G.; Middleton, B.; Lowden, A.; Marqueze, E.; França-Junior, I.; Antunes, J.L.F.; Cipolla-Neto, J.; Skene, D.J.; Moreno, C.R.C. Melatonin profiles during the third trimester of pregnancy and health status in the offspring among day and night workers: A case series. Neurobiol. Sleep Circadian Rhythm. 2019, 6, 70-76. [CrossRef]

55. Strohmaier, S.; Devore, E.E.; Vetter, C.; Eliassen, A.H.; Rosner, B.; Okereke, O.I.; Schernhammer, E.S. Night shift work before and during pregnancy in relation to depression and anxiety in adolescent and young adult offspring. Eur. J. Epidemiol. 2019, 34, 625-635. [CrossRef] 
56. Tain, Y.L.; Lin, Y.J.; Chan, J.Y.H.; Lee, C.T.; Hsu, C.N. Maternal melatonin or agomelatine therapy prevents programmed hypertension in male offspring of mother exposed to continuous light. Biol. Reprod. 2017, 97, 636-643. [CrossRef]

57. Voiculescu, S.E.; Le Duc, D.; Roșca, A.E.; Zeca, V.; Chiţimuș, D.M.; Arsene, A.L.; Drăgoi, C.M.; Nicolae, A.C.; Zăgrean, L.; Schöneberg, T.; et al. Behavioral and molecular effects of prenatal continuous light exposure in the adult rat. Brain Res. 2016, 1650, 51-59. [CrossRef]

58. Vilches, N.; Spichiger, C.; Mendez, N.; Abarzua-Catalan, L.; Galdames, H.A.; Hazlerigg, D.G.; Richter, H.G.; Torres-Farfan, C. Gestational chronodisruption impairs hippocampal expression of NMDA receptor subunits Grin1b/Grin3a and spatial memory in the adult offspring. PLoS ONE 2014, 9, e91313. [CrossRef]

59. Varcoe, T.J.; Wight, N.; Voultsios, A.; Salkeld, M.D.; Kennaway, D.J. Chronic phase shifts of the photoperiod throughout pregnancy programs glucose intolerance and insulin resistance in the rat. PLoS ONE 2011, 6, e18504. [CrossRef]

60. Mendez, N.; Halabi, D.; Spichiger, C.; Salazar, E.R.; Vergara, K.; Alonso-Vasquez, P.; Carmona, P.; Sarmiento, J.M.; Richter, H.G.; Seron-Ferre, M.; et al. Gestational chronodisruption impairs circadian physiology in rat male offspring, increasing the risk of chronic disease. Endocrinology 2016, 157, 4654-4668. [CrossRef]

61. Smarr, B.L.; Grant, A.D.; Perez, L.; Zucker, I.; Kriegsfeld, L.J. Maternal and Early-Life Circadian Disruption Have Long-Lasting Negative Consequences on Offspring Development and Adult Behavior in Mice. Sci. Rep. 2017, 7, 3326. [CrossRef] [PubMed]

62. Carmona, P.; Pérez, B.; Trujillo, C.; Espinosa, G.; Miranda, F.; Mendez, N.; Torres-Farfan, C.; Richter, H.G.; Vergara, K.; Brebi, P.; et al. Long-Term Effects of Altered Photoperiod During Pregnancy on Liver Gene Expression of the Progeny. Front. Physiol. 2019, 10, 1377. [CrossRef] [PubMed]

63. Vázquez, N.; Díaz, E.; Fernández, C.; Jiménez, V.; Esquifino, A.; Díaz, B. Seasonal variations of gonadotropins and prolactin in the laboratory rat. Role of maternal pineal gland. Physiol. Res. 2007, 56, 79-88. [PubMed]

64. Workman, J.L.; Weil, Z.M.; Tuthill, C.R.; Nelson, R.J. Maternal pinealectomy increases depressive-like responses in Siberian hamster offspring. Behav. Brain Res. 2008, 189, 387-391. [CrossRef]

65. Ferreira, D.S.; Amaral, F.G.; Mesquita, C.C.; Barbosa, A.P.; Lellis-Santos, C.; Turati, A.O.; Santos, L.R.; Sollon, C.S.; Gomes, P.R.; Faria, J.A.; et al. Maternal melatonin programs the daily pattern of energy metabolism in adult offspring. PLoS ONE 2012, 7, e38795. [CrossRef]

66. Spulber, S.; Conti, M.; DuPont, C.; Raciti, M.; Bose, R.; Onishchenko, N.; Ceccatelli, S. Alterations in circadian entrainment precede the onset of depression-like behavior that does not respond to fluoxetine. Transl. Psychiatry 2015, 5, e603. [CrossRef]

67. Tsai, C.C.; Tiao, M.M.; Sheen, J.M.; Huang, L.T.; Tain, Y.L.; Lin, I.C.; Lin, Y.J.; Lai, Y.J.; Chen, C.C.; Chang, K.A.; et al. Obesity programmed by prenatal dexamethasone and postnatal high-fat diet leads to distinct alterations in nutrition sensory signals and circadian-clock genes in visceral adipose tissue. Lipids Health Dis. 2019, 18, 19. [CrossRef]

68. Tain, Y.L.; Sheen, J.M.; Chen, C.C.; Yu, H.R.; Tiao, M.M.; Kuo, H.C.; Huang, L.T. Maternal citrulline supplementation prevents prenatal dexamethasone-induced programmed hypertension. Free Radic. Res. 2014, 48, 580-586. [CrossRef]

69. Tiao, M.M.; Huang, L.T.; Chen, C.J.; Sheen, J.M.; Tain, Y.L.; Chen, C.C.; Kuo, H.C.; Huang, Y.H.; Tang, K.S.; $\mathrm{Chu}, \mathrm{E} . \mathrm{W}$; et al. Melatonin in the regulation of liver steatosis following prenatal glucocorticoid exposure. Biomed. Res. Int. 2014, 2014, 942172. [CrossRef]

70. Lui, C.C.; Hsu, M.H.; Kuo, H.C.; Chen, C.C.; Sheen, J.M.; Yu, H.R.; Tiao, M.M.; Tain, Y.L.; Chang, K.A.; Huang, L.T. Effects of melatonin on prenatal dexamethasone-induced epigenetic alterations in hippocampal morphology and reelin and glutamic acid decarboxylase 67 levels. Dev. Neurosci. 2015, 37, 105-114. [CrossRef]

71. Sheen, J.M.; Yu, H.R.; Tiao, M.M.; Chen, C.C.; Huang, L.T.; Chang, H.Y.; Tain, Y.L. Prenatal dexamethasone-induced programmed hypertension and renal programming. Life Sci. 2015, 132, 41-48. [CrossRef] [PubMed]

72. Kuo, A.H.; Li, J.; Li, C.; Huber, H.F.; Schwab, M.; Nathanielsz, P.W.; Clarke, G.D. Prenatal steroid administration leads to adult pericardial and hepatic steatosis in male baboons. Int. J. Obes. 2017, 41, 1299-1302. [CrossRef] [PubMed] 
73. Tang, L.; Carey, L.C.; Bi, J.; Valego, N.; Sun, X.; Deibel, P.; Perrott, J.; Figueroa, J.P.; Chappell, M.C.; Rose, J.C. Gender differences in the effects of antenatal betamethasone exposure on renal function in adult sheep. Am. J. Physiol. Regul. Integr. Comp. Physiol. 2009, 296, R309-R317. [CrossRef] [PubMed]

74. Sloboda, D.M.; Moss, T.J.; Li, S.; Matthews, S.G.; Challis, J.R.; Newnham, J.P. Expression of glucocorticoid receptor, mineralocorticoid receptor, and 11beta-hydroxysteroid dehydrogenase 1 and 2 in the fetal and postnatal ovine hippocampus: Ontogeny and effects of prenatal glucocorticoid exposure. J. Endocrinol. 2008, 197, 213-220. [CrossRef]

75. Borisenkov, M.F.; Kosova, A.L.; Kasyanova, O.N. Impact of perinatal photoperiod on the chronotype of 11to 18-year-olds in northern European Russia. Chronobiol. Int. 2012, 29, 305-310. [CrossRef]

76. Cheng, T.S.; Loy, S.L.; Cheung, Y.B.; Cai, S.; Colega, M.T.; Godfrey, K.M.; Chong, Y.S.; Tan, K.H.; Shek, L.P.; Lee, Y.S.; et al. Plasma Vitamin D Deficiency Is Associated With Poor Sleep Quality and Night-Time Eating at Mid-Pregnancy in Singapore. Nutrients 2017, 9, 340. [CrossRef]

77. Versteeg, R.I.; Serlie, M.J.; Kalsbeek, A.; la Fleur, S.E. Serotonin, a possible intermediate between disturbed circadian rhythms and metabolic disease. Neuroscience 2015, 301, 155-167. [CrossRef]

78. Shibata, S.; Moore, R.Y. Development of a fetal circadian rhythm after disruption of the maternal circadian system. Brain Res. 1988, 469, 313-317. [CrossRef]

79. Hoogerwerf, W.A.; Hellmich, H.L.; Cornélissen, G.; Halberg, F.; Shahinian, V.B.; Bostwick, J.; Savidge, T.C.; Cassone, V.M. Clock gene expression in the murine gastrointestinal tract: Endogenous rhythmicity and effects of a feeding regimen. Gastroenterology 2007, 133, 1250-1260. [CrossRef]

80. Dolatshad, H.; Campbell, E.A.; O’Hara, L.; Maywood, E.S.; Hastings, M.H.; Johnson, M.H. Developmental and reproductive performance in circadian mutant mice. Hum. Reprod. 2006, 21, 68-79. [CrossRef]

81. Tain, Y.L.; Hsu, C.N. Interplay between oxidative stress and nutrient sensing signaling in the developmental origins of cardiovascular disease. Int. J. Mol. Sci. 2017, 18, 841. [CrossRef] [PubMed]

82. Thompson, L.P.; Al-Hasan, Y. Impact of oxidative stress in fetal programming. J. Pregnancy 2012, $2012,582748$. [CrossRef] [PubMed]

83. Bogdarina, I.; Welham, S.; King, P.J.; Burns, S.P.; Clark, A.J. Epigenetic modification of the renin-angiotensin system in the fetal programming of hypertension. Circ. Res. 2007, 100, 520-526. [CrossRef] [PubMed]

84. Bianco-Miotto, T.; Craig, J.M.; Gasser, Y.P.; van Dijk, S.J.; Ozanne, S.E. Epigenetics and DOHaD: From basics to birth and beyond. J. Dev. Orig. Health Dis. 2017, 8, 513-519. [CrossRef]

85. Cottrell, E.C.; Seckl, J.R. Prenatal stress, glucocorticoids and the programming of adult disease. Front. Behav. Neurosci. 2009, 3, 19. [CrossRef]

86. Colin-Gonzalez, A.L.; Aguilera, G.; Serratos, I.N.; Escribano, B.M.; Santamaria, A.; Tunez, I. On the Relationship between the Light/Dark Cycle, Melatonin and Oxidative Stress. Curr. Pharm. Des. 2015, 21,3477-3488. [CrossRef]

87. Cugini, P.; Lucia, P. Circadian rhythm of the renin-angiotensin-aldosterone system: A summary of our research studies. Clin. Ter. 2004, 155, 287-291.

88. Du, S.; Chen, L.; Ge, L.; Huang, W. A Novel Loop: Mutual Regulation between Epigenetic Modification and the Circadian Clock. Front. Plant Sci. 2019, 10, 22. [CrossRef]

89. Nicolaides, N.C.; Charmandari, E.; Chrousos, G.P.; Kino, T. Circadian endocrine rhythms: The hypothalamic-pituitary-adrenal axis and its actions. Ann. N. Y. Acad. Sci. 2014, 1318, 71-80. [CrossRef]

90. Chen, Y.C.; Sheen, J.M.; Tiao, M.M.; Tain, Y.L.; Huang, L.T. Roles of melatonin in fetal programming in compromised pregnancies. Int. J. Mol. Sci. 2013, 14, 5380-5401. [CrossRef]

91. Reiter, R.J.; Tan, D.X.; Terron, M.P.; Flores, L.J.; Czarnocki, Z. Melatonin and its metabolites: New findings regarding their production and their radical scavenging actions. Acta Biochim. Pol. 2007, 54, 1-9. [CrossRef] [PubMed]

92. Tain, Y.L.; Huang, L.T.; Hsu, C.N.; Lee, C.T. Melatonin therapy prevents programmed hypertension and nitric oxide deficiency in offspring exposed to maternal caloric restriction. Oxidative Med. Cell Longev. 2014, 2014, 283180. [CrossRef] [PubMed]

93. Gao, L.; Zhao, Y.C.; Liang, Y.; Lin, X.H.; Tan, Y.J.; Wu, D.D.; Li, X.Z.; Ye, B.Z.; Kong, F.Q.; Sheng, J.Z.; et al. The impaired myocardial ischemic tolerance in adult offspring of diabetic pregnancy is restored by maternal melatonin treatment. J. Pineal Res. 2016, 61, 340-352. [CrossRef] [PubMed] 
94. Tain, Y.Y.; Lee, W.C.; Hsu, C.N.; Lee, W.C.; Huang, L.T.; Lee, C.T.; Lin, C.Y. Asymmetric dimethylarginine is associated with developmental programming of adult kidney disease and hypertension in offspring of streptozotocin-treated mothers. PLoS ONE 2013, 8, e55420. [CrossRef]

95. Shirpoor, A.; Nemati, S.; Ansari, M.H.; Ilkhanizadeh, B. The protective effect of vitamin E against prenatal and early postnatal ethanol treatment-induced heart abnormality in rats: A 3-month follow-up study. Int. Immunopharmacol. 2015, 26, 72-79. [CrossRef]

96. Wang, X.; Wang, J.; Luo, H.; Chen, C.; Pei, F.; Cai, Y.; Yang, X.; Wang, N.; Fu, J.; Xu, Z.; et al. Prenatal lipopolysaccharide exposure causes mesenteric vascular dysfunction through the nitric oxide and cyclic guanosine monophosphate pathway in offspring. Free Radic. Biol. Med. 2015, 86, 322-330. [CrossRef]

97. Gwathmey, T.M.; Shaltout, H.A.; Rose, J.C.; Diz, D.I.; Chappell, M.C. Glucocorticoid-induced fetal programming alters the functional complement of angiotensin receptor subtypes within the kidney. Hypertension 2011, 57, 620-626. [CrossRef]

98. Tain, Y.L.; Lee, C.T.; Chan, J.Y.; Hsu, C.N. Maternal melatonin or N-acetylcysteine therapy regulates hydrogen sulfide-generating pathway and renal transcriptome to prevent prenatal N(G)-Nitro-L-arginine-methyl ester (L-NAME)-induced fetal programming of hypertension in adult male offspring. Am. J. Obstet. Gynecol. 2016, 215, 636. [CrossRef]

99. Giussani, D.A.; Camm, E.J.; Niu, Y.; Richter, H.G.; Blanco, C.E.; Gottschalk, R.; Blake, E.Z.; Horder, K.A.; Thakor, A.S.; Hansell, J.A.; et al. Developmental programming of cardiovascular dysfunction by prenatal hypoxia and oxidative stress. PLoS ONE 2012, 7, e31017. [CrossRef]

100. Tain, Y.L.; Chan, J.Y.H.; Lee, C.T.; Hsu, C.N. Maternal Melatonin Therapy Attenuates Methyl-Donor Diet-Induced Programmed Hypertension in Male Adult Rat Offspring. Nutrients 2018, 10, 1407. [CrossRef]

101. Tain, Y.L.; Leu, S.; Wu, K.L.; Lee, W.C.; Chan, J.Y. Melatonin prevents maternal fructose intake-induced programmed hypertension in the offspring: Roles of nitric oxide and arachidonic acid metabolites. J. Pineal Res. 2014, 57, 80-89. [CrossRef] [PubMed]

102. Te Riet, L.; van Esch, J.H.; Roks, A.J.; van den Meiracker, A.H.; Danser, A.H. Hypertension: Renin-angiotensin-aldosterone system alterations. Circ. Res. 2015, 116, 960-975. [CrossRef] [PubMed]

103. Lemmer, B. Signal Transduction and Chronopharmacology of Regulation of Circadian Cardiovascular Rhythms in Animal Models of Human Hypertension. Heart Fail. Clin. 2017, 13, 739-757. [CrossRef] [PubMed]

104. Simko, F.; Reiter, R.J.; Pechanova, O.; Paulis, L. Experimental models of melatonin-deficient hypertension. Front. Biosci. 2013, 18, 616-625. [CrossRef]

105. Kett, M.M.; Denton, K.M. Renal programming: Cause for concern? Am. J. Physiol. Regul. Integr. Comp. Physiol. 2011, 300, R791-R803. [CrossRef]

106. Tain, Y.L.; Huang, L.T.; Chan, J.Y.; Lee, C.T. Transcriptome analysis in rat kidneys: Importance of genes involved in programmed hypertension. Int. J. Mol. Sci. 2015, 16, 4744-4758. [CrossRef]

107. Chappell, M.C.; Marshall, A.C.; Alzayadneh, E.M.; Shaltout, H.A.; Diz, D.I. Update on the Angiotensin converting enzyme 2-Angiotensin (1-7)-MAS receptor axis: Fetal programing, sex differences, and intracellular pathways. Front. Endocrinol. 2014, 4, 201. [CrossRef]

108. Cisternas, C.D.; Compagnucci, M.V.; Conti, N.R.; Ponce, R.H.; Vermouth, N.T. Protective effect of maternal prenatal melatonin administration on rat pups born to mothers submitted to constant light during gestation. Braz. J. Med. Biol. Res. 2010, 43, 874-882. [CrossRef]

109. Tain, Y.L.; Sheen, J.M.; Yu, H.R.; Chen, C.C.; Tiao, M.M.; Hsu, C.N.; Lin, Y.J.; Kuo, K.C.; Huang, L.T. Maternal Melatonin Therapy Rescues Prenatal Dexamethasone and Postnatal High-Fat Diet Induced Programmed Hypertension in Male Rat Offspring. Front. Physiol. 2015, 6, 377. [CrossRef]

110. Naruse, Y.; Oh-hashi, K.; Iijima, N.; Naruse, M.; Yoshioka, H.; Tanaka, M. Circadian and light-induced transcription of clock gene Per1 depends on histone acetylation and deacetylation. Mol. Cell. Biol. 2004, 24, 6278-6287. [CrossRef]

111. Sahar, S.; Sassone-Corsi, P. The epigenetic language of circadian clocks. Handb. Exp. Pharmacol. 2013, $217,29-44$.

112. Wu, T.H.; Kuo, H.C.; Lin, I.C.; Chien, S.J.; Huang, L.T.; Tain, Y.L. Melatonin prevents neonatal dexamethasone induced programmed hypertension: Histone deacetylase inhibition. J. Steroid Biochem. Mol. Biol. 2014, 144, 253-259. [CrossRef] [PubMed] 
113. Tain, Y.L.; Chen, C.C.; Sheen, J.M.; Yu, H.R.; Tiao, M.M.; Kuo, H.C.; Huang, L.T. Melatonin attenuates prenatal dexamethasone-induced blood pressure increase in a rat model. J. Am. Soc. Hypertens. 2014, 8, $216-226$. [CrossRef] [PubMed]

114. Pattison, P.M.; Tsao, J.Y.; Brainard, G.C.; Bugbee, B. LEDs for photons, physiology and food. Nature 2018, 563, 493-500. [CrossRef]

115. Azeemi, S.T.Y.; Rafiq, H.M.; Ismail, I.; Kazmi, S.R.; Azeemi, A. The mechanistic basis of chromotherapy: Current knowledge and future perspectives. Complement. Ther. Med. 2019, 46, 217-222. [CrossRef]

116. Chien, A.L.; Qi, J.; Rainer, B.; Sachs, D.L.; Helfrich, Y.R. Treatment of Acne in Pregnancy. J. Am. Board Fam. Med. 2016, 29, 254-262. [CrossRef]

117. Traverzim, M.A.D.S.; Makabe, S.; Silva, D.F.T.; Pavani, C.; Bussadori, S.K.; Fernandes, K.S.P.; Motta, L.J. Effect of led photobiomodulation on analgesia during labor: Study protocol for a randomized clinical trial. Medicine 2018, 97, e11120. [CrossRef]

118. Riemann, D.; Baglioni, C.; Bassetti, C.; Bjorvatn, B.; Dolenc Groselj, L.; Ellis, J.G.; Espie, C.A.; Garcia-Borreguero, D.; Gjerstad, M.; Gonçalves, M.; et al. European guideline for the diagnosis and treatment of insomnia. J. Sleep Res. 2017, 26, 675-700. [CrossRef]

119. Leach, M.J.; Page, A.T. Herbal medicine for insomnia: A systematic review and meta-analysis. Sleep Med. Rev. 2015, 24, 1-12. [CrossRef]

120. Gitto, E.; Aversa, S.; Reiter, R.J.; Barberi, I.; Pellegrino, S. Update on the use of melatonin in pediatrics. J. Pineal Res. 2011, 50, 21-28. [CrossRef]

121. Sanchez-Barcelo, E.J.; Rueda, N.; Mediavilla, M.D.; Martinez-Cue, C.; Reiter, R.J. Clinical Uses of Melatonin in Neurological Diseases and Mental and Behavioural Disorders. Curr. Med. Chem. 2017, 24, 3851-3878. [CrossRef] [PubMed]

122. Carpentieri, A.; Díaz de Barboza, G.; Areco, V.; Peralta López, M.; Tolosa de Talamoni, N. New perspectives in melatonin uses. Pharmacol. Res. 2012, 65, 437-444. [CrossRef] [PubMed]

123. Foley, H.M.; Steel, A.E. Adverse events associated with oral administration of melatonin: A critical systematic review of clinical evidence. Complement. Ther. Med. 2019, 42, 65-81. [CrossRef] [PubMed]

124. Hsu, C.N.; Huang, L.T.; Tain, Y.L. Perinatal Use of Melatonin for Offspring Health: Focus on Cardiovascular and Neurological Diseases. Int. J. Mol. Sci. 2019, 20, 5681. [CrossRef] [PubMed]

125. Tain, Y.L.; Joles, J.A. Reprogramming: A preventive strategy in hypertension focusing on the kidney. Int. J. Mol. Sci. 2015, 17, 23. [CrossRef] [PubMed]

126. Baydas, G.; Koz, S.T.; Tuzcu, M.; Nedzvetsky, V.S. Melatonin prevents gestational hyperhomocysteinemia-associated alterations in neurobehavioral developments in rats. J. Pineal Res. 2008, 44, 181-188. [CrossRef] [PubMed]

127. Dubovický, M.; Ujházy, E.; Kovacovský, P.; Navarová, J.; Juráni, M.; Soltés, L. Effect of melatonin on neurobehavioral dysfunctions induced by intrauterine hypoxia in rats. Cent. Eur. J. Public Health 2004, 12 (Suppl.), S23-S25.

128. Tain, Y.L.; Leu, S.; Lee, W.C.; Wu, K.L.H.; Chan, J.Y.H. Maternal Melatonin Therapy Attenuated Maternal High-Fructose Combined with Post-Weaning High-Salt Diets-Induced Hypertension in Adult Male Rat Offspring. Molecules 2018, 23, 886. [CrossRef]

129. Tsai, C.C.; Lin, Y.J.; Yu, H.R.; Sheen, J.M.; Lin, I.C.; Lai, Y.J.; Tain, Y.L.; Huang, L.T.; Tiao, M.M. Regulation of Leptin Methylation Not via Apoptosis by Melatonin in the Rescue of Chronic Programming Liver Steatosis. Int. J. Mol. Sci. 2018, 19, 3565. [CrossRef]

130. Tsai, C.C.; Lin, Y.J.; Yu, H.R.; Sheen, J.M.; Tain, Y.L.; Huang, L.T.; Tiao, M.M. Melatonin alleviates liver steatosis induced by prenatal dexamethasone exposure and postnatal high-fat diet. Exp. Ther. Med. 2018, 16, 917-924. [CrossRef]

131. Figueiró, P.W.; de S Moreira, D.; Dos Santos, T.M.; Prezzi, C.A.; Rohden, F.; Faccioni-Heuser, M.C.; Manfredini, V.; Netto, C.A.; Wyse, A.T.S. The neuroprotective role of melatonin in a gestational hypermethioninemia model. Int. J. Dev. Neurosci. 2019, 78, 198-209. [CrossRef] [PubMed]

(C) 2020 by the authors. Licensee MDPI, Basel, Switzerland. This article is an open access article distributed under the terms and conditions of the Creative Commons Attribution (CC BY) license (http://creativecommons.org/licenses/by/4.0/). 